Vol. 5 (1996): 209-217.

\title{
A linkage map of spring turnip rape based on RFLP and RAPD markers
}

\author{
Pirjo K. Tanhuanpää \\ Agricultural Research Centre of Finland, Institute of Crop and Soil Science, FIN-31600 Jokioinen, Finland \\ Juha P. Vilkki \\ Boreal Plant Breeding, FIN-31600 Jokioinen, Finland \\ H. Johanna Vilkki \\ Agricultural Research Centre of Finland, Institute of Animal Production, FIN-31600 Jokioinen, Finland
}

\begin{abstract}
A linkage map of spring turnip rape (Brassica rapa ssp. oleifera) was constructed from an $\mathrm{F}_{2}$ population of a cross Jo4002 x Sv3402. The map contained 22 RFLP loci, 144 RAPDs, one microsatellite, and one morphological marker (seed colour). All ten B.rapa linkage groups could be identified and the total map distance was $519 \mathrm{cM}$. A proportion of the markers (13\%), most of which were located in two linkage groups, showed segregation distortion.
\end{abstract}

Key words: DNA polymorphism, microsatellite, segregation distortion

\section{Introduction}

The development of highly polymorphic DNA markers has facilitated the construction of genetic linkage maps. During the last few years linkage maps have been developed for many plant species, e.g. in the genus Brassica for B.oleracea (Slocum et al. 1990, Kianian and Quiros 1992, Landry et al. 1992), B.napus (Landry et al. 1991, Ferreira et al. 1994, Uzunova et al. 1995), and B.rapa (Song et al. 1991, Chyi et al. 1992, Teutonico and Osborn 1994).

The most commonly used type of DNA marker in linkage studies has been restriction frag- ment length polymorphism (RFLP). Recently developed marker types based on use of the polymerase chain reaction (PCR) such as random amplified polymorphic DNA (RAPD), have several advantages over RFLPs. RAPD analysis is easy to perform and rapid, and does not require the use of radioactivity. In addition, because only minute amounts of crude template DNA are needed, it is possible to use rapid smallscale DNA extraction methods. A disadvantage is that the dominant nature of RAPD markers can cause problems if an $\mathrm{F}_{2}$ intercross population is used. In such cases, estimation of recombination frequency is very inefficient between repulsion phase markers (Ott 1985) and, there- 


\section{AGRICULTURAL AND FOOD SCIENCE IN FINLAND}

Tanhuanpää, P.K., Vilkki, J.P. \& Vilkki, H.J.: A linkage map of spring turnip rape

fore, two maps including only coupling phase markers have to be constructed.

Existing B.rapa linkage maps are mostly composed of RFLP markers. Our aim here was to construct a linkage map of spring turnip rape (B.rapa ssp. oleifera) consisting mainly of RAPD markers. RFLP markers were used to integrate our map with the existing B.rapa map (Teutonico and Osborn 1994).

\section{Material and methods}

\section{Plant material}

The $\mathrm{F}_{2}$ mapping population was derived by selfpollinating five $\mathrm{F}_{1}$ individuals from a cross between two individuals of repeatedly selfed spring turnip rape lines Jo4002 and Sv3402. The linkage data are mostly based on $77 \mathrm{~F}_{2}$ individuals; 28 additional plants were scored to confirm linkages between some markers.

DNA of the plants was extracted by a method slightly modified from that of Dellaporta et al. (1983), as described by Tanhuanpää et al. (1993).

\section{Markers}

RFLP analysis was performed using standard methods (Maniatis et al. 1982) with restriction enzymes EcoRI or HindIII as described by Tanhuanpää et al. (1994). The $\mathrm{F}_{2}$ progeny was screened with 24 DNA clones from B.rapa or B.napus (Teutonico and Osborn 1994) and two PCR-amplified genomic sequences of Brassicaceae: the Brassica self-incompatibility gene SLG-8 (Dwyer et al. 1991), and the 5-enolpyruvylshikimate-3-phosphate synthase (EPSPS) gene from B.napus (Gasser and Klee 1990).

RAPD primers were either synthesised on an Applied Biosystems 392 DNA/RNA Synthesizer (Table 1) or purchased from Operon Technologies (Alameda, California, USA). RAPD analysis was performed as described in Tanhuanpää et al. (1995a) with minor modifications. Putat-
Table 1. RAPD primers used to analyse the $\mathrm{F}_{2}$ progeny of the B.rapa ssp. oleifera cross, Jo4002 x Sv3402. In addition, primers from Operon Technologies were used.

\begin{tabular}{|c|c|c|c|c|}
\hline \multirow{2}{*}{$\frac{\text { Primer }}{10}$} & \multicolumn{4}{|c|}{ Sequence $5^{\prime}$ to $3^{\prime}$} \\
\hline & GCT & GCT & CGA & GT \\
\hline 11 & CGT & CCT & TAA & GC \\
\hline 14 & GCA & CTG & TCG & $\mathrm{AC}$ \\
\hline 19 & CGC & TCT & AGA & $\mathrm{CC}$ \\
\hline 20 & TGC & CAG & TTA & CG \\
\hline 25 & GCG & TGT & AGG & CT \\
\hline 26 & GGA & ATC & TCG & GT \\
\hline 33 & CCG & CTT & AGT & TC \\
\hline 45 & AGA & CGA & TGT & AC \\
\hline 63 & GAC & CGT & GAG & $\mathrm{AC}$ \\
\hline 65 & ACG & TGC & ATG & G \\
\hline 72 & TGG & ACT & CGA & G \\
\hline 74 & GCT & GAC & TCG & AG \\
\hline 75 & $\mathrm{CGA}$ & ACC & TGA & TC \\
\hline 76 & ATC & GTC & GAT & GC \\
\hline 77 & GCT & AGC & TAC & TG \\
\hline 78 & AGT & CGA & CTT & $\mathrm{C}$ \\
\hline 90 & ACG & CTA & GAC & CT \\
\hline 93 & GGT & ACT & CGA & CT \\
\hline 101 & ATG & CGT & CAG & TC \\
\hline 102 & TGA & TCG & ACT & CG \\
\hline 103 & CGT & TCG & AGT & CT \\
\hline 105 & TGC & ATC & GTA & $\mathrm{C}$ \\
\hline 107 & GAC & TCG & AGA & $\mathrm{C}$ \\
\hline 110 & ACG & CCG & TAC & G \\
\hline 111 & TCG & GAA & GGA & C \\
\hline 112 & GGA & CAC & TAC & $\mathrm{T}$ \\
\hline 117 & GCG & CAA & GTG & $\mathrm{AA}$ \\
\hline 118 & CGT & CGC & TGT & $\mathrm{T}$ \\
\hline 123 & ACT & GAG & CGT & G \\
\hline 127 & CAG & СТC & AGG & CT \\
\hline 129 & GTC & CAC & GTA & GC \\
\hline 130 & ACT & CTG & GCA & G \\
\hline 134 & GAC & TGT & GCA & $\mathrm{T}$ \\
\hline 137 & CTA & CAT & GCA & CG \\
\hline 138 & GTC & CAC & AGA & $\mathrm{T}$ \\
\hline 140 & ACG & CTA & TGA & C \\
\hline 141 & CTG & ATC & TGC & A \\
\hline 146 & GCT & TCA & TCG & TG \\
\hline 147 & CGT & TCA & СCT & C \\
\hline 148 & CCG & $\mathrm{ACT}$ & TCC & A \\
\hline 149 & TGC & CAG & TCT & $\mathrm{CC}$ \\
\hline 164 & AGA & AAT & GGG & G \\
\hline
\end{tabular}

ive allelism of two RAPD markers was investigated by hybridisation using one of the RAPD bands as a probe. 
Vol. 5 (1996): 209-217.

Table 2. B.napus microsatellites used to search for polymorphism between the parents of the B.rapa ssp. oleifera cross, Jo4002 and Sv3402. '-' indicates no identifiable amplification.

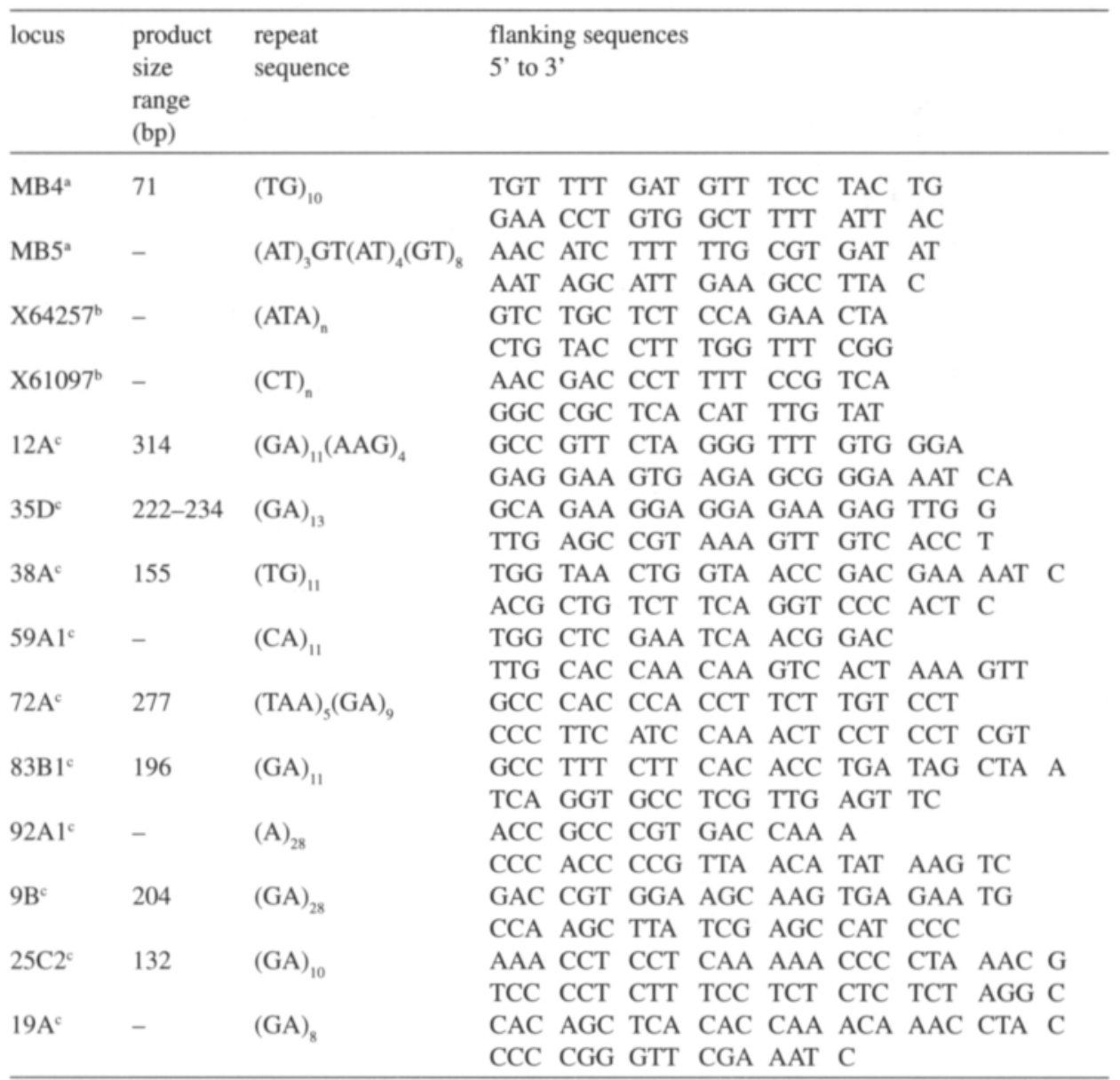

"Lagercrantz et al. (1993)

${ }^{b}$ Microsatellites from the EMBL and GenBank databases

${ }^{c}$ Kresovich et al. (1995), Dr A. Szewc-McFadden, pers. comm.

PCR programs used are those in the respective articles, microsatellites from databases amplified with the program described by Lagercrantz et al.

Microsatellites are simple DNA sequences consisting of repeated nucleotide motifs, and show extensive polymorphism due to the occurrence of different numbers of repeat units. The microsatellites (Table 2) were amplified in PCR using a pair of flanking primers, one primer of each pair labelled with fluorescein. The amplified products were visualised with ALF DNA Sequencer (Pharmacia).
One morphological marker, seed colour, which exhibits dominant inheritance ('brown' dominant over 'yellow'), was scored visually in the $\mathrm{F}_{2}$ population.

\section{Nomenclature}

RFLP probes and the respective loci (Fig.1) were named according to Teutonico and Osborn 


\section{AGRICULTURAL AND FOOD SCIENCE IN FINLAND}

Tanhuanpää, P.K., Vilkki, J.P. \& Vilkki, H.J.: A linkage map of spring turnip rape

(1994): with the prefix WG (genomic DNA clones from B.napus cv 'Westar'), TG (genomic DNA clones from B.rapa cv 'Tobin') or EC (cDNA clones from B.napus cv 'Westar').

RAPD loci (Fig.1) were named by the primer: self-synthesised primers with plain numbers, and Operon primers with a letter and a number. Different polymorphic markers produced by the same primer were assigned with a small letter following the number of the primer (Table 3 ).

The microsatellite marker on the map has the prefix MS.

The nomenclature of ten B.rapa linkage groups (LG1-LG10) follows that on the previous map (Teutonico and Osborn 1994), the groups being identified by the common RFLP loci. Unassigned groups were named with capital letters (A-C, Fig. 1).

\section{Statistical analysis}

Because the inbred lines Jo4002 and Sv3402 contained residual heterozygosity, the $\mathrm{F}_{1}$ seed was not uniform. Some marker loci were homozygous in some of the five $F_{1}$ individuals, leading to genetically uniform (with respect to these loci) $\mathrm{F}_{2}$ progeny which had to be omitted in the linkage analysis. Therefore, the number of segregating individuals within the pooled $\mathrm{F}_{2}$ population varied from locus to locus.

Goodness-of-fit to the expected $\mathrm{F}_{2}$ segregation at marker loci was tested by chi-square ana- lysis. Linkage relationships were evaluated by the MAPMAKER 3.0 computer program (Lander et al. 1987). Markers were grouped with a LOD score of 4.0 and a maximum recombination fraction of 0.4 as linkage criteria. On a few occasions, the LOD score threshold for linkage was decreased to 2.0 to include additional RFLP loci (indicated with a dashed line in Fig. 1) on the map. Map distances in centiMorgans were computed by Haldane's mapping function. Separate linkage analyses were performed for data set A (dominant markers originating from Jo4002) and data set B (dominant markers from Sv3402). Codominant markers were present in both data sets.

The map was built in two phases. First, a framework map was constructed from data set A, using only those markers that could be ordered with a LOD score difference $>3.0$ (in some cases 2.0) in favour of the best map. To build up the final linkage map, all the other markers linked to each group with a LOD score $>4.0$ were placed to the side of the closest framework locus (markers from data set $\mathrm{A}$ and codominant markers to the left and markers from data set B to the right).

\section{Results}

A high level of DNA polymorphism was observed in the mapping population: $67 \%$ of the

Fig.1. Linkage map of B.rapa ssp. oleifera constructed from the $\mathrm{F}_{2}$ population of a cross, Jo4002 x Sv3402. For grouping markers, a LOD score threshold of 4.0 was used, except for TG1H12 and WG1G6, which were attached to the framework using a LOD score of 2.0 (indicated with a dashed line). For ordering, a LOD score difference $>3.0$ (wider line) or $>2.0$ (LGs 4, 6, 7, slim line) in favour of the best map was used. Dominant RAPD markers on the framework and on its left side are derived from Jo4002 (data set A), on the right side from Sv3402 (data set B). Marker distances are shown in centimorgans; for markers not included in the framework, two point map distances between the marker and the nearest framework locus are shown (LG9 includes four markers, 65a, 93a, 147b, 140d, which did not show linkage to any framework markers but only to markers from data set B). Linkage groups are named after the previous B.rapa RFLP map (Teutonico and Osborn 1994); the orientation of groups LG1, 6, 7 and 8, where only one locus is common with the previous map, is arbitrary. Codominant markers are underlined, loci common with the previous map printed in italics. The nomenclature of markers is described in Material and methods. Loci exhibiting aberrant segregation are indicated with $*(\mathrm{P}<0.05),{ }^{* *}(\mathrm{P}<0.01)$ or ***(P<0.001). LG10 is split into two parts, which probably represent distal segments of the same chromosome, because in data set B the codominant markers in these segments map to opposite ends of the same linkage group. Groups B and C contain markers from data set B only. 
Vol. 5 (1996): 209-217.

LG1

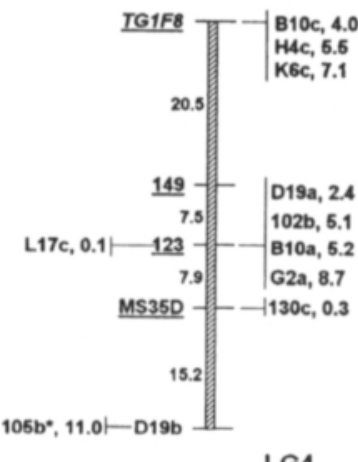

LG4

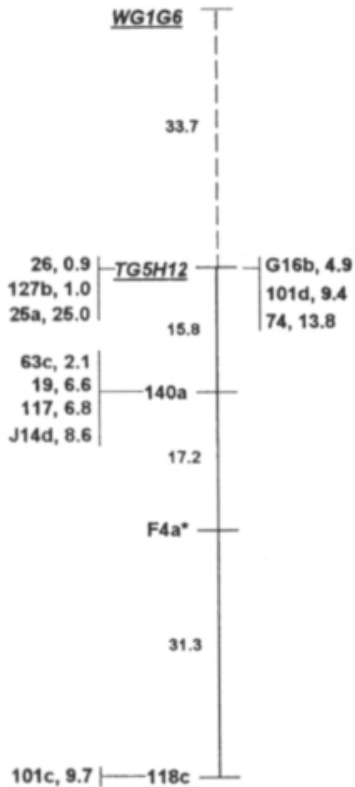

LG8

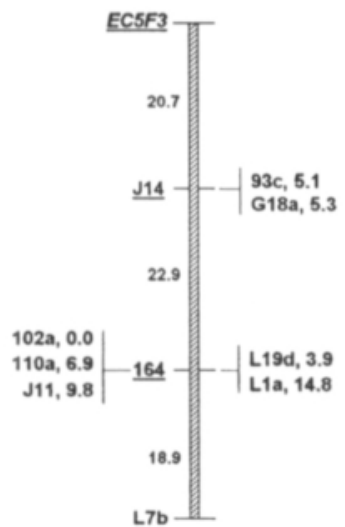

LG2

LG3

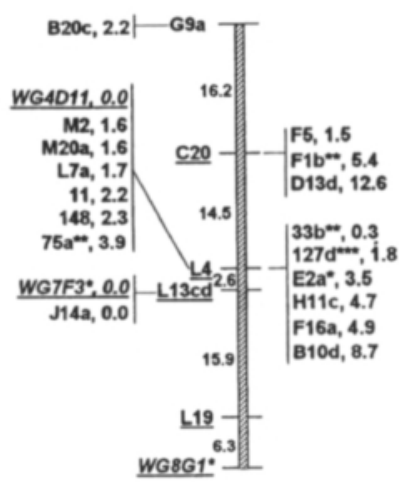

LG5

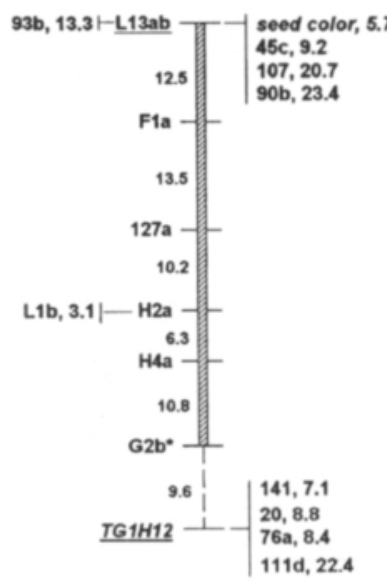

LG9

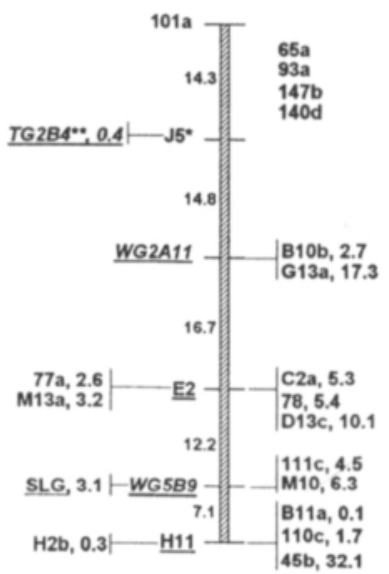

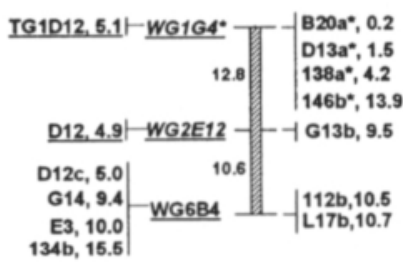

LG6

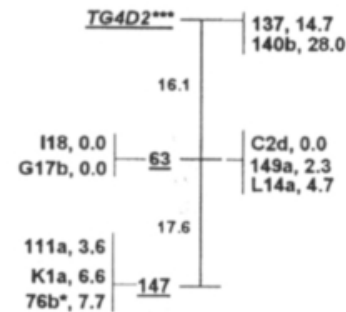

LG7

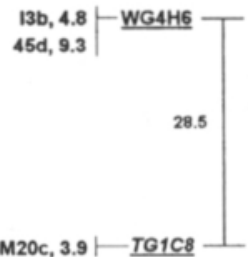

M20c, 3.9

LG10

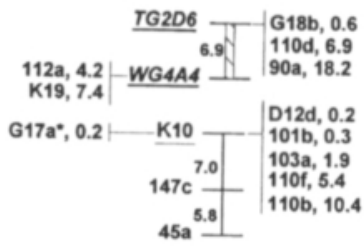

Group A Group B

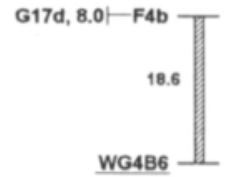

Group C

$118 \mathrm{a}$
$118 \mathrm{~b}$

$118 \mathrm{~b}$ 
Tanhuanpää, P.K., Vilkki, J.P. \& Vilkki, H.J.: A linkage map of spring turnip rape

\begin{tabular}{|c|c|}
\hline Primer & Marker size $(\mathrm{kb})$ \\
\hline 11 & 0.9 \\
\hline 19 & 0.7 \\
\hline 20 & 1.6 \\
\hline 25 & 2.2 (a) \\
\hline 26 & 0.4 \\
\hline 33 & 0.9 (b) \\
\hline 45 & 1.0 (a), 1.1 (b), 1.6 (c), 0.6 (d) \\
\hline 63 & $1.4(\mathrm{~b}), 0.5(\mathrm{c}), 1.3(\mathrm{~d})$ \\
\hline 65 & $2.1(\mathrm{a})$ \\
\hline 74 & 1.4 \\
\hline 75 & 0.5 (a) \\
\hline 76 & 0.9 (a), 0.6 (b) \\
\hline 77 & $1.6(\mathrm{a})$ \\
\hline 78 & 1.2 \\
\hline 90 & $1.6(\mathrm{a}), 1.2(\mathrm{~b})$ \\
\hline 93 & $1.2(\mathrm{a}), 0.6(\mathrm{~b}), 0.6(\mathrm{c})$ \\
\hline 101 & 1.4 (a), 1.6 (b), 1.2 (d) \\
\hline 102 & 1.7 (a), 1.2 (b) \\
\hline 103 & 0.2 (a) \\
\hline 105 & 1.0 (b) \\
\hline 107 & 0.7 \\
\hline 110 & 2.5 (a), 2.2 (b), 2.1 (c), 1.4 (d), 0.8 (f) \\
\hline 111 & 1.9 (a), $1.0(\mathrm{c}), 1.3(\mathrm{~d})$ \\
\hline 112 & $2.5(\mathrm{a}), 0.9(\mathrm{~b})$ \\
\hline 117 & 1.8 \\
\hline 118 & 2.0 (a), 1.8 (b), 1.5 (c) \\
\hline 123 & $1.5(a), 1.3(b), 1.0(\mathrm{c})$ \\
\hline 127 & 2.4 (a), 2.2 (b), 1.2 (d) \\
\hline 130 & $1.1(\mathrm{c})$ \\
\hline 134 & $0.5(b)$ \\
\hline 137 & 0.5 \\
\hline 138 & 1.8 (a) \\
\hline 140 & 3.0 (a), 2.3 (b), 0.9 (d) \\
\hline 141 & 0.9 \\
\hline 146 & 0.7 (b) \\
\hline 147 & 2.3 (b), 2.2 (c), $1.0(\mathrm{e}), 0.9$ (f) \\
\hline 148 & 0.4 \\
\hline 149 & $2.0(\mathrm{a}), 1.3(\mathrm{~b}), 1.3(\mathrm{c})$ \\
\hline 164 & $0.8(\underline{a}), 0.7(\underline{b})$ \\
\hline
\end{tabular}

Table 3. The approximate size of the RAPD markers included in the B.rapa map. The markers have the same name as the respective primer; in cases where a primer produces more than one polymorphic marker, lower case letters differentiate between the markers. Codominant markers are

81 RFLP probes and $79 \%$ of the 340 RAPD primers tested detected polymorphism between the parents of the cross, Jo4002 and Sv3402.

\begin{tabular}{|c|c|}
\hline Primer & Marker size (kb) \\
\hline B10 & 1.4 (a), 1.0 (b), 0.7 (c), 0.3 (d) \\
\hline B11 & $1.0(\mathrm{a}), 0.8(\mathrm{~b})$ \\
\hline B20 & $2.1(\mathrm{a}), 0.8(\mathrm{c})$ \\
\hline $\mathrm{CO} 2$ & 1.1 (a), $0.5(d)$ \\
\hline $\mathrm{C} 20$ & $1.9(a), 1.9(\underline{b})$ \\
\hline D12 & 2.0 (a), 1.9 (b), 1.7 (c), 1.6 (d) \\
\hline D13 & $0.8(\mathrm{a}), 0.6(\mathrm{c}), 0.5(\mathrm{~d})$ \\
\hline D19 & $1.3(\mathrm{a}), 0.8$ (b) \\
\hline E02 & $1.2(\mathrm{a}), 0.5(\underline{b}), 0.5(\underline{c})$ \\
\hline E03 & 1.0 \\
\hline F01 & $1.3(\mathrm{a}), 1.0(\mathrm{~b})$ \\
\hline F04 & $1.5(\mathrm{a}), 1.0(\mathrm{~b})$ \\
\hline F05 & 0.9 \\
\hline F16 & 2.5 (a) \\
\hline G02 & $2.0(\mathrm{a}), 1.1(\mathrm{~b})$ \\
\hline G09 & 1.9 (a) \\
\hline G13 & 1.4 (a), 0.9 (b) \\
\hline G14 & 1.0 \\
\hline G16 & 1.4 (b) \\
\hline G17 & 1.4 (a), 1.3 (b), 0.5 (d) \\
\hline G18 & $1.3(\mathrm{a}), 1.2(\mathrm{~b})$ \\
\hline $\mathrm{H} 02$ & $1.0(\mathrm{a}), 0.9$ (b) \\
\hline H04 & 0.8 (a), 0.6 (c), 0.4 (d) \\
\hline H11 & $1.9(\underline{a}), 1.8(\underline{b}), 1.3(\mathrm{c})$ \\
\hline I03 & $1.8(\mathrm{~b})$ \\
\hline I18 & 1.0 \\
\hline J05 & 0.7 \\
\hline J11 & 1.2 \\
\hline J14 & 1.3 (a), 1.2 (b), 1.2 (c), 0.7 (d) \\
\hline K01 & 2.8 (a) \\
\hline K06 & $1.1(\mathrm{c})$ \\
\hline K10 & 0.7 (a), 0.6 (b) \\
\hline K19 & 0.6 \\
\hline L01 & $1.8(\mathrm{a}), 1.4(\mathrm{~b})$ \\
\hline L04 & 0.6 (a), $0.5(\underline{b}), 0.4$ (c) \\
\hline L07 & $1.4(a), 0.9$ (b) \\
\hline L13 & 2.4 (a), 2.3 (b), 1.3 (c), 1.3 (d) \\
\hline L14 & 0.7 (a) \\
\hline L17 & $1.1(\mathrm{~b}), 0.8(\mathrm{c})$ \\
\hline L19 & 1.5 (b), 1.4 (c), 1.1 (d) \\
\hline M02 & 0.9 \\
\hline M10 & 1.2 \\
\hline M13 & 1.0 (a) \\
\hline M20 & $0.8(\mathrm{a}), 0.7$ (c) \\
\hline
\end{tabular}

underlined; lower case letters are not used in their name on the map (Fig. 1).

Only one (35D) of the 14 microsatellites tested could be used as a marker; the others either detected no polymorphism, could not be inter- 
Vol. 5 (1996): 209-217.

preted, or the primers failed to amplify detectable products (Table 2 ). The $\mathrm{F}_{2}$ population was scored with a total of 26 RFLP probes, 90 RAPD primers, one microsatellite and one morphological marker. The 90 RAPD primers amplified 176 reproducible polymorphic loci, of which 15 exhibited codominant inheritance.

The 114 loci in data set A were arranged into twelve linkage groups, 3-16 markers each. In data set B (132 loci) 11 linkage groups with 3-20 markers each were found. Twenty markers in data set $\mathrm{A}$ and 27 markers in data set $\mathrm{B}$ remained unlinked.

Data set $\mathrm{A}$ was used for building the framework map, because all ten major linkage groups identified on the previous map (Teutonico and Osborn 1994) could be found. The framework map consisted of 48 markers, 32 showing codominant inheritance. The length of the linkage groups ranged from $6.9 \mathrm{cM}$ to $98 \mathrm{cM}$, the total map distance being $519 \mathrm{cM}$.

The final linkage map, with markers from both data sets, was composed of 58 dominant markers from Jo4002, 71 dominant markers from Sv3402, 38 codominant markers and one morphological marker (Fig. 1). A total of 18 markers (printed in italics) were common with those of the previous map of Teutonico and Osborn (1994). Three triplets of linked markers were unassigned (groups A-C) and 32 individual loci remained unlinked.

Twenty markers (5 RFLPs and 15 RAPDs) on the final linkage map and seven unlinked markers exhibited distorted segregation (13\% in total). Most of the mapped markers with skewed segregation clustered to linkage groups LG2 and LG3 and were distorted towards the Jo4002 allele. All except one of the distorted RAPD markers in LG2 and LG3 were derived from data set B (dominant allele from Sv3402).

\section{Discussion}

In this study, a linkage map of B.rapa ssp. oleifera was built from an $\mathrm{F}_{2}$ population of the cross Jo4002 x Sv3402. Mainly RAPD markers were used, and all ten linkage groups of B.rapa could be identified.

Although repulsion phase markers were not used, it was impossible to order all markers accurately; the best order was usually only slightly more probable than the alternatives. There are a couple of explanations for this. First, estimation of recombination frequencies (and thus ordering of loci) between dominant markers is more inefficient than between codominant ones (Ott 1985). This holds true especially when the recombination fraction is small, which was the case in some chromosomal segments where markers appeared to cluster.

Second, the residual heterozygosity in the parents resulted in a reduced size of the $\mathrm{F}_{2}$ progeny for some loci. This sometimes led to situations where the number of common informative loci between individuals was too low for a reliable estimation of recombination frequency. Finally, errors in genotyping may have caused ambiguity in the placement of loci. The inability to order all the loci reliably resulted in a total map length of only $519 \mathrm{cM}$; the total length of the map of Teutonico and Osborn (1994) was $1785 \mathrm{cM}$.

The clustering of loci to some map positions may reflect suppressed recombination in heterochromatic regions (Roberts 1965). It may, however, also be due to limited resolution of the map. Clustering of loci has been reported in maps of various different species (e.g. sugar beet, Barzen et al. 1995; Arabidopsis, Reiter et al. 1992; and Lactuca sativa, Kesseli et al. 1994).

Interestingly, loci with distorted segregation ratios mapped primarily to LG2 and LG3, and were skewed towards Jo4002 alleles. The clustering of skewed loci may indicate the existence of gametic or zygotic lethal alleles or gametophytic selection, i.e. gametes containing these regions of the Jo4002 genome were more competitive. Similar findings of skewed clusters have been reported in various plant species, e.g. B.rapa (Chyi et al. 1992, Teutonico and Osborn 1994), B.napus (Landry et al. 1991), Hordeum vulgare (Giese et al. 1994), Lactuca sativa (Kes- 


\section{AGRICULTURAL AND FOOD SCIENCE IN FINLAND}

Tanhuanpää, P.K., Vilkki, J.P. \& Vilkki, H.J.: A linkage map of spring turnip rape

seli et al. 1994), Beta vulgaris (Barzen et al. 1995) and Medicago sativa (Echt et al. 1993). Our results agreed with those of Teutonico and Osborn (1994) in having a cluster of skewed loci in LG2.

This is the first reported linkage map mostly consisting of RAPD loci in B.rapa. Not all the loci could be ordered unambiguously, which, however, does not diminish the value of the map. The loci can later be mapped more precisely in regions of particular interest by analysing more $\mathrm{F}_{2}$ individuals. The map has already been used to find a QTL for palmitic acid (in LG9, Tanhuanpää et al. 1995b) and for oleic acid (in LG6, Tanhuanpää et al. 1996), and will be used in future studies.

Our previous work (Tanhuanpää et al. 1996) demonstrates the possibility of transferring RAPD marker information from one cross to another, and thus, the map can provide information for other researchers, too. In that work (Tanhuanpää et al. 1996), we studied the occurrence of a total of 20 markers in two different $\mathrm{F}_{2}$ populations: one was derived from a cross between one individual from the line Jo4002 and another individual from the line Jo4072; the other population was the same as that used here, i.e. derived from the cross Jo4002 x Sv3402. Ten of the markers studied were derived from the parent, which differed in the two populations, and in those cases the probability of finding the same marker in the two populations was $40 \%$.

Acknowledgements. We thank Ms Leena Lamminpää for the pollinations, Ms Marja-Riitta Mäkelä for her skillful technical assistance and Ms Anneli Virta for the microsatellite analyses. The study was supported in part by the Finnish Ministry of Agriculture and Forestry.

\section{References}

Barzen, E., Mechelke, W., Ritter, E., Schulte-Kappert, E. \& Salamini, F. 1995. An extended map of sugar beet genome containing RFLP and RAPD loci. Theoretical and Applied Genetics 90:189-193.

Chyi, Y.-S., Hoenecke, M.E. \& Sernyk, J.L. 1992. A genetic linkage map of restriction fragment length polymorphism loci in Brassica rapa (syn. campestris). Genome 35:746-757.

Dellaporta, S.L., Wood, J. \& Hicks, J.B. 1983. A plant DNA minipreparation: version II. Plant Molecular Biology Reporter 1: 19-21.

Dwyer, K.G., Balent, M.A., Nasrallah, J.B. \& NasralIah, M.E. 1991. DNA sequences of self- incompatibility genes from Brassica campestris and B.oleracea: polymorphism predating speciation. Plant Molecular Biology 16: 481-486.

Echt, C.S., Kidwell, K.K., Knapp, S.J., Osborn, T.C. \& McCoy, T.J. 1993. Linkage mapping in diploid alfalfa (Medicago sativa). Genome 37: 61-71.

Ferreira, M.E., Williams, P.H. \& Osborn, T.C. 1994. RFLP mapping of Brassica napus using doubled haploid lines. Theoretical and Applied Genetics 89: 615-621.

Gasser, C.S. \& Klee, H.J. 1990. A Brassica napus gene encoding 5-enolpyruvylshikimate-3-phosphate synthase. Nucleic Acids Research 19:2821.

Giese, H., Holm-Jensen, A.G., Mathiassen, H., Kjœr, B., Rasmussen, S.K., Bay, H. \& Jensen, J. 1994. Distribution of RAPD markers on a linkage map of barley. Hereditas 120: 267-273.
Kesseli, R.V., Paran, I. \& Michelmore, R.W. 1994. Analysis of a detailed genetic linkage map of Lactuca sativa (lettuce) constructed from RFLP and RAPD markers. Genetics 136: 1435-1446.

Kianian, S.F. \& Quiros, C.F. 1992. Generation of a Brassica oleracea composite RFLP map: linkage arrangements among various populations and evolutionary implications. Theoretical and Applied Genetics 84: 544-554. Kresovich, S., Szewc-McFadden, A.K., Bliek, S.M. \& McFerson, J.R. 1995. Abundance and characterization of simple-sequence repeats (SSRs) isolated from a sizefractionated genomic library of Brassica napus L. (rapeseed). Theoretical and Applied Genetics 91: 206-211.

Lagercrantz, U., Ellegren, H. \& Andersson, L. 1993. The abundance of various polymorphic microsatellite motifs differs between plants and vertebrates. Nucleic Acids Research 21: 1111-1115.

Lander, E.S., Green, P., Abrahamson, J., Barlow, A., Daly, M.J., Lincoln, S.E. \& Newburg, L. 1987. MAPMAKER: An interactive computer package for constructing primary genetic linkage maps of experimental and natural populations. Genomics 1: 174-181.

Landry, B.S., Hubert, N., Etoh, T., Harada, J.J. \& Lincoln, S.E. 1991. A genetic map for Brassica napus based on restriction fragment length polymorphisms detected with expressed DNA sequences. Genome 34: 543-552. - , Hubert, N., Crete, R., Chang, M., Lincoln, S.E. \& Etoh, T. 1992. A genetic map of Brassica oleracea based on RFLP markers detected with expressed DNA sequences 
Vol. 5 (1996): 209-217.

and mapping of resistance genes to race 2 of Plasmodiophora brassica (Woronin). Genome 35: 409-419.

Maniatis, T., Fritsch, E.F. \& Sambrook, J. 1982. Molecular cloning: A laboratory manual. Cold Spring Harbor Laboratory, Cold Spring Harbor/NY.

Ott, J. 1985. Analysis of human genetic linkage. John Hopkins University Press, Baltimore, Maryland.

Reiter, R.S., Williams, J.G.K., Feldmann, K.A., Rafalski, J.A., Tingey, S.V. \& Scolnik, P.A. 1992. Global and local genome mapping in Arabidopsis thaliana by using recombinant inbred lines and random amplified polymorphic DNAs. Proceedings of National Academy of Sciences, USA 89: 1477-1481.

Roberts, P.A. 1965. Difference in the behavior of eu- and hetero-chromatin: crossing over. Nature 205: 725-726. Slocum, M.K., Figdore, S.S., Kennard, W.C., Suzuki, J.Y. \& Osborn, T.C. 1990. Linkage arrangement of restriction fragment length polymorphism loci in Brassica oleracea. Theoretical and Applied Genetics 80: 57-64.

Song, K.M., Suzuki, J.Y., Slocum, M.K., Williams, P.H. \& Osborn, T.C. 1991. A linkage map of Brassica rapa (syn. campestris) based on restriction fragment length polymorphism loci. Theoretical and Applied Genetics 82: 296-304.

Tanhuanpää, P.K., Vilkki, H.J., Vilkki, J.P. \& Pulli, S.K. 1993. Genetic polymorphism at RAPD loci in spring turnip rape (Brassica rapa ssp. oleifera). Agricultural Sci- ence in Finland 2: 303-310.

- , Vilkki, J.P. \& Vilkki, H.J. 1994. Segregation and linkage analysis of DNA markers in microspore derived and $\mathrm{F}_{2}$ populations of oilseed rape (Brassica napus L.). Euphytica 74:59-65.

- , Vilkki, J.P. \& Vilkki, H.J. 1995a. Association of a RAPD marker with linolenic acid concentration in the seed oil of rapeseed (Brassica napus L.). Genome 38: 414416.

- , Vilkki, J.P. \& Vilkki, H.J. 1995b. Identification of a RAPD marker for palmitic-acid concentration in the seed oil of spring turnip rape (Brassica rapa ssp. oleifera). Theoretical and Applied Genetics 91: 477-480.

- , Vilkki, J.P. \& Vilkki, H.J. 1996. Mapping of a QTL for oleic acid concentration in spring turnip rape (Brassica rapa ssp. oleifera). Theoretical and Applied Genetics 92: 952-956.

Teutonico, R.A. \& Osborn, T.C. 1994. Mapping of RFLP and qualitative trait loci in Brassica rapa and comparison to the linkage maps of B.napus, B.oleracea, and Arabidopsis thaliana. Theoretical and Applied Genetics 89: 885-894.

Uzunova, M., Ecke, W., Weissleder, K. \& Röbbelen, G. 1995. Mapping the genome of rapeseed (Brassica napus L.).1. Construction of an RFLP linkage map and localization of QTLs for seed glucosinolate content. Theoretical and Applied Genetics 90: 194-204.

\title{
SELOSTUS
}

\section{RAPD- ja RFLP-markkereista koostuva rypsin kytkentäkartta}

\author{
Pirjo Tanhuanpää, Juha Vilkki ja Johanna Vilkki \\ Maatalouden tutkimuskeskus ja Boreal Suomen Kasvinjalostus
}

Rypsin kytkentäkartan laatimista varten kasvatettiin $F_{2}$ populaatio, jonka vanhempina olivat yksilöt kevätrypsilinjoista Jo4002 ja Sv3402. DNA-polymorfia oli runsasta tässä karttapopulaatiossa: testatuista 81 RFLP-probista $67 \%$ ja testatuista 340 RAPD-primerista $79 \%$ oli polymorfisia risteytysvanhemmissa. Lopullinen kartta koostui 168 markkerista, joista 144 oli RAPD-markkereita, 22 RFLP-markkereita, yksi morfologinen markkeri (siemenen väri) ja yksi mikrosatelliitti. Kaikki rypsin 10 kytkentäryhmää pystyt- tiin tunnistamaan, ja kartan kokonaispituus oli $519 \mathrm{cM}$. Markkereista $13 \%$ ei segregoitunut normaalisti, ja suurin osa näistä markkereista kartoittui vain kahteen kytkentäryhmään. Kartta on ensimmäinen julkaistu rypsin kartta, jossa suurin osa markkereista on RAPDeja. Karttaa on jo aiemmin käytetty hyväksi paikallistettaessa palmitiini- ja öljyhappopitoisuuksiin vaikuttavat geenit, ja tulevaisuudessa sitä käytetään myös muiden tärkeisiin ominaisuuksiin vaikuttavien geenien kartoittamiseen. 